\title{
Neospora caninum infection in cattle in the state of Amazonas, Brazil: seroprevalence, spatial distribution and risk factors
}

\author{
Infecção por Neospora caninum em bovinos no estado do Amazonas, Brasil: \\ soroprevalência, distribuição espacial e fatores de risco
}

\author{
Paulo Cesar Gonçalves de Azevedo Filho1; Müller Ribeiro-Andrade2; Jomel Francisco dos Santos; \\ Arthêmio Coelho dos Reis ${ }^{3}$; José Wilton Pinheiro Júnior ${ }^{4}$; Sandra Regina Fonseca de Araújo Valença4; \\ Erika Fernanda Torres Samico-Fernandes4; Rinaldo Aparecido Mota ${ }^{4 *}$ (i) \\ ${ }^{1}$ Instituto Federal de Educação, Ciência e Tecnologia do Amazonas - IFAM, Campus Manaus Zona Leste, Manaus, AM, Brasil \\ ${ }^{2}$ Instituto de Ciências Biológicas e Saúde, Universidade Federal de Alagoas - UFAL, Maceió, AL, Brasil \\ ${ }^{3}$ Agência de Agricultura e Proteção Florestal do Amazonas - ADAF, Manaus, AM, Brasil \\ ${ }^{4}$ Departamento de Medicina Veterinária, Universidade Federal Rural de Pernambuco - UFRPE, Recife, PE, Brasil
}

How to cite: Azevedo Filho PCG, Ribeiro-Andrade M, Santos JF, Reis AC, Pinheiro Júnior JW, Valença SRFA, et al. Neospora caninum infection in cattle in the state of Amazonas, Brazil: seroprevalence, spatial distribution and risk factors. Braz J Vet Parasitol 2021; 30(1): e020820. https://doi.org/10.1590/S1984-296120201083

\begin{abstract}
Livestock in the Amazon has grown significantly and, although neosporosis in cattle has been reported worldwide, there is no information about $N$. caninum in production systems in the state of Amazonas. The objective of this study was to determine the prevalence of anti-Neospora caninum antibodies in cattle, their spatial distribution and the risk factors associated with $N$. caninum infection in the state of Amazonas. Questionnaires were applied to farmers to assess risk factors associated with $N$. caninum infection. Blood samples were collected from 1,073 animals on 47 farms in 33 municipalities in the four Amazonian subpopulations. IgG anti-N.caninum antibodies were detected by the indirect fluorescence test, with a general prevalence of 30.2\%, being seropositive in 43 farms (91.5\%), with prevalence ranging from $2.2 \%$ to $69.2 \%$. The highest number of high density points was found in subpopulation 3 (municipality of Apuí and other municipalities on the Madeira River and affluent). It was concluded that $N$. caninum is present with high seroprevalence values, when compared to other cattle producing states in the Amazon region of Brazil. The identified factors can be used as risk indicators so that control measures can be implemented to prevent infection by N. caninum in these herds.
\end{abstract}

Keywords: Amazon rainforest, Neospora caninum, prevalence, IFAT, cattle, Brazil.

\begin{abstract}
Resumo
A pecuária na Amazônia tem crescido significativamente e, embora a neosporose em bovinos tenha sido relatada em todo o mundo, não há informações sobre $N$. caninum nos sistemas de produção no estado do Amazonas. Objetivou-se determinar a prevalência de anticorpos anti-Neospora caninum em bovinos, sua distribuição espacial e os fatores de risco associados à infecção por N. caninum no estado do Amazonas. Questionários foram aplicados aos fazendeiros, para avaliar fatores de risco associados à infecção por $N$. caninum. Amostras de sangue foram coletadas de 1.073 animais em 47 fazendas, em 33 municípios das quatro subpopulações amazonenses. Anticorpos IgG anti-N.caninum foram detectados pelo teste de imunofluorescência indireta, com prevalência geral de 30,2\%, com soropositividade em 43 fazendas $(91,5 \%)$, com prevalência variando de $2,2 \%$ a $69,2 \%$. O maior número de pontos de alta densidade foi encontrado na subpopulação 3 (município de Apuí e demais municípios do rio Madeira e afluentes). Concluiu-se que $N$. caninum está presente com altos valores de soroprevalência, quando comparado a outros estados produtores de gado na região amazônica do Brasil. Os fatores identificados podem ser usados como indicadores de risco, para que medidas de controle possam ser implementadas para prevenir a infecção por N. caninum nesses rebanhos.
\end{abstract}

Palavras-chave: Floresta Amazônica, Neospora caninum, prevalência, IFI, gado, Brasil. 


\section{Introduction}

In Brazil's Amazon region, composed of municipalities in the states of Rondônia, Acre, Amazonas, Roraima, Pará, Amapá, Tocantins, Mato Grosso, Maranhão, the herds of the states of the Amapá, Roraima, Amazonas and Acre, together, represented only 5.9\% of the total for the region (Valentim \& Andrade, 2009). Amazonas is estimated to have 1.48 million head of cattle, which corresponds to only $0.69 \%$ of the national herd (ADAF, 2019). Several obstacles hinder the development of beef cattle in this state. Factors such as deforestation, pasture degradation, high rainfall indices, and lack of information about diseases that affect zootechnical indices all contribute to meager production and economic rates (Arima et al., 2005). Infectious diseases are considered an important etiological cause of losses in cattle herds (Pinheiro et al., 2000; Reichel et al., 2013), above all neosporosis, which is considered the main disease associated with reproductive impairment in cows in different regions around the world (Dubey et al., 2007; Dubey \& Schares, 2011; McAllister, 2016). In Brazil, this infection is considered prevalent throughout the territory (Cerqueira-Cézar et al., 2017).

Neosporosis is caused by the coccidium Neospora caninum. The main pathways of transmission of this disease are transplacental and the ingestion of sporulated oocysts excreted in the environment by the definitive hosts, especially domestic dogs (McAllister et al., 1998; Donahoe et al., 2015). The pathogenicity of $N$. caninum varies according to its host species. Cattle are the most susceptible hosts, and the disease causes abortions, stillbirths and the birth of weak calves. $N$. caninum infection in cattle is reported in every continent where cattle are raised (Dubey \& Schares, 2011). However, prevalence rates of the infection in cattle herds vary significantly, depending on factors such as production systems, the presence of definitive hosts, herd health management (Ghalmi et al., 2012).

Several studies have been conducted in different regions of Brazil to detect anti-N. caninum IgG antibodies in cattle, whose prevalence ranges from 9.1\% to 97.2\% (Hasegawa et al., 2004; Vianna et al., 2008; Andreotti et al., 2010; Amaral et al., 2012; Silva et al., 2017). In the Amazon region, N. caninum infection has been described in the states of Pará (Minervino et al., 2008; Silva et al., 2017), Rondônia (Aguiar et al., 2006; Boas et al., 2015) and Tocantins (Martins et al., 2011), with prevalence rates varying from 10.4\% to 52\%. However, there are no seroepidemiological studies of $N$. caninum infection in the state of Amazonas, so there is a gap in information about herd health and factors associated with infection in this region of the country. Thus, our aim was to determine the seroprevalence, spatial distribution and risk factors associated with Neospora caninum infection in cattle herds in the state of Amazonas.

\section{Material and Methods}

\section{Farms and sampling}

This study was approved by the Ethics Committee on Animal Use (CEUA) of the Federal Rural University of Pernambuco (UFRPE), under protocol no. 80/2018.

Farms were selected in the four subpopulations in the state of Amazonas, defined by the Ministry of Agriculture, Livestock and Food Supply - MAPA (Brasil, 2019) (see Figure 1). These subpopulations are as follows: Subpopulation 1 - comprising the municipalities of Rio Negro and its tributaries; Subpopulation 2 - composed of the municipalities of Rio Solimões and its tributaries; Subpopulation 3 - comprising the municipality of Apuí and the other municipalities of the Madeira River and its tributaries, and Subpopulation 4 - comprising the other municipalities of the state of Amazonas on its border with the state of Pará.

Blood samples were collected from 1073 reproductively mature cows (older than 24 months) on farms with more than 10 cattle (primary sampling units) in 33 municipalities in the state of Amazonas. The animals were identified individually by an ear tag usually attached to the left ear. This tag number was recorded on the label of the vacutainer tube and on a sample collection form. For the study sample calculation, an expected prevalence of $50 \%, 95 \%$ confidence and 5\% statistical error were considered (Thrusfield, 2004).

\section{Sample collection for serology}

Blood samples were collected by venipuncture of the external jugular vein into sterile and tagged vacutainer tubes. Ten $\mathrm{mL}$ of blood without anticoagulant were drawn into individual test tubes after prior skin antisepsis with $3.0 \%$ iodinated alcohol. The samples were centrifuged at $1000 \times g$ for five minutes to obtain serum. The blood sera were aliquoted and stored at $-20^{\circ} \mathrm{C}$ until serological tests were performed. 


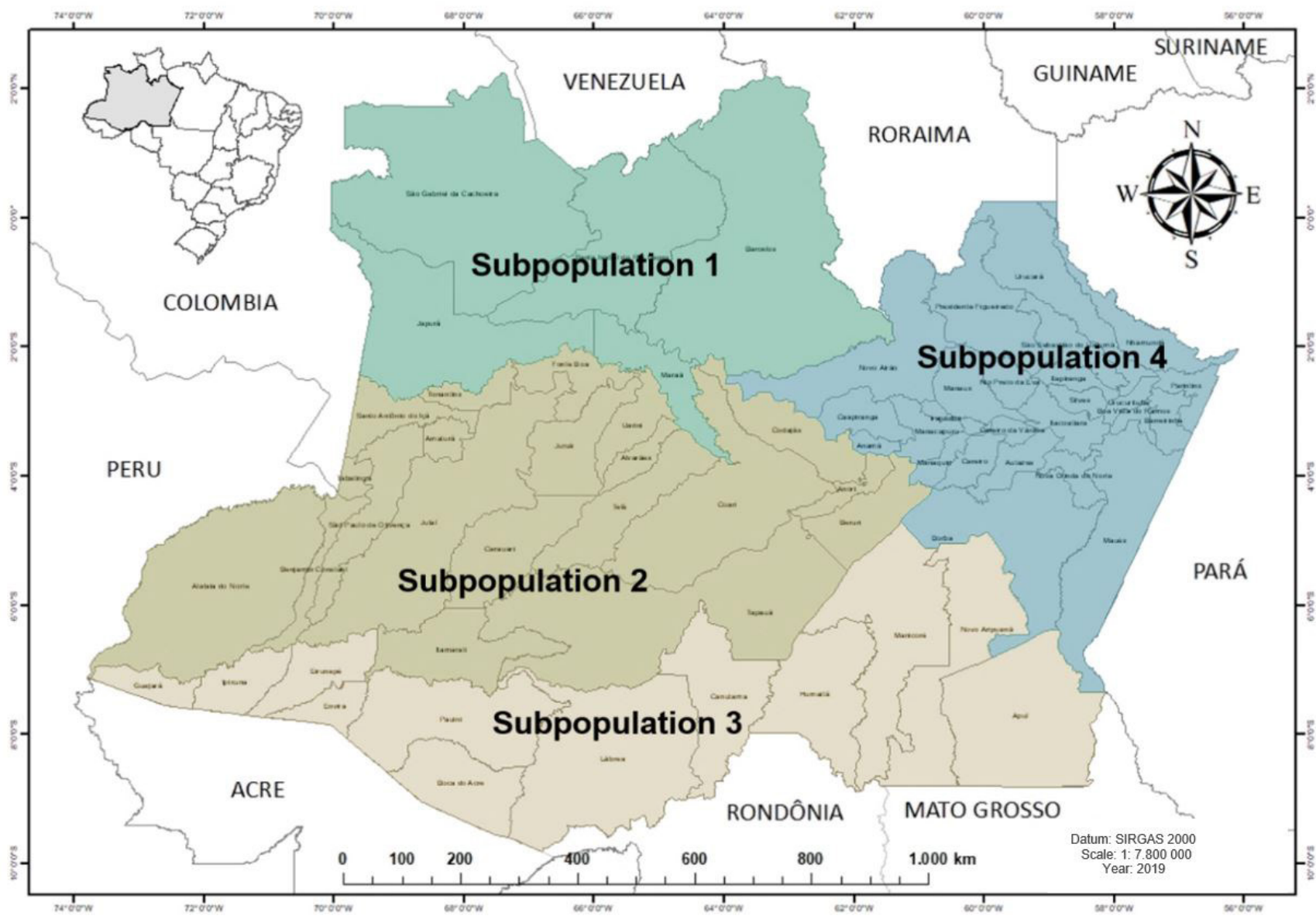

Figure 1. Map of the subpopulations (1, 2, 3, and 4) of the state of Amazonas, according to the Ministry of Agriculture (Brasil, 2019), Livestock and Supply of Brazil.

\section{Preparation of antigen for the IFAT}

Neospora caninum antigen stored in a culture of MARC-145 cell monolayers was used, according to the conditions described by Regidor-Cerrillo et al. (2010). The number of viable tachyzoites was determined by counting in a Neubauer chamber using $0.2 \%$ trypan blue. The purified tachyzoites were suspended in $0.6 \%$ formalin solution in PBS, adjusted to a concentration of 1200-1500 parasites/ $\mu \mathrm{L}$, and each well of the slides for the indirect fluorescent antibody test (IFAT) was sensitized with $10 \mu \mathrm{L}$ of the tachyzoite suspension. All the microscope slides were fixed in acetone at $-20^{\circ} \mathrm{C}$ and stored under refrigeration until use. All slides were fixed in acetone at $-20^{\circ} \mathrm{C}$ and stored under refrigeration until use.

\section{Survey of anti-N. caninum IgG antibodies}

To begin with, serum samples were diluted 1:200 (cutoff) (Gondim et al., 1999) in 1X PBS, distributed in the wells of the sensitized slides and incubated in a humidifying chamber at $37^{\circ} \mathrm{C}$ for $30 \mathrm{~min}$. The slides were then washed and reincubated with fluorescein isothiocyanate-conjugated anti-bovine IgG serum (Sigma Chemical, USA) containing 0.02\% Evans blue (Sigma Chemical, USA). Lastly, the slides were washed again, covered with buffered glycerine and coverslips and examined under an epifluorescence microscope (Nikon Eclipse 40x objective lens). Samples were considered positive when $50 \%$ of the tachyzoites in the wells presented total peripheral fluorescence (Kim et al., 2019). Serum samples known to be positive and negative were included as control samples. Positive control sera were obtained from cattle with consistently positive serological results by IFI and negative control sera from healthy cattle with consistently negative serological results by IFI, as mentioned above. The slides were examined by an epifluorescent microscope (Olympus, Mod. BH2, Tokyo, Japan). 


\section{Spatial distribution and of N. caninum infection}

The coordinates of each farm were determined by georeferencing, using a TrackMaker ${ }^{\circledR}$ PRO GPS to characterize the map of the state of Amazonas, Brazil. The georeferenced data were entered into the ArcMap version 12.2.2 program, using the Kernel Density Estimator (KDE), which is a non-parametric technique that allows the variability of a data set to be filtered while preserving the essential local characteristics of the data (Bailey \& Gatrell, 1995). The parameter used for elaboration of the maps using the KDE was the frequency of $N$. caninum-positive cattle per farm studied. This frequency was classified in ranges and the density expressed by color: very high (red color), high (dark orange color), medium (yellow color), low (green), very low (yellow color) and negative (blue). The number of farms located in the different areas was counted on the maps resulting from this operation.

\section{Risk factors associated with N. caninum infection}

Pre-structured questionnaires were applied the farmers to assess the risk factors associated with $N$. caninum infection, variables included in the analysis final model were: type of farming system (type of herd; livestock farming system; farm size; herd size) and management-related (water source; presence of other domestic and wild animals; occurrence of abortion; birth of weak calves).

The absolute and relative frequencies were subjected to dispersion. The risk factors associated with Neospora caninum infection were studied based on an analysis of the variables of interest using Pearson's chi-square test or Fisher's exact test, when necessary. A logistic regression analysis was then performed, considering the IFAT results (positive or negative) as the dependent variable. The independent or explanatory variables considered in the final model were those with a statistical significance of $<0.05$. The statistical calculations were made using Epi Info version 3.5.1 software.

\section{Results}

The prevalence of anti-Neospora caninum antibodies in cattle in the state of Amazonas was 30.2\% (324/1073; CI 95\%: $27.5 \%$ - 33.0). The frequencies of each the subpopulations are shown in Table 1. No significant differences $(p>0.05)$ were observed between the prevalence of subpopulations.

Table 1. Prevalence of Neospora caninum infection in cattle per subpopulations (1,2,3 and 4$)$ in the state of Amazonas, Brazil.

\begin{tabular}{cccc}
\hline Subpopulation & Total No. of animals & No. positive animals & $\begin{array}{c}\text { Neospora caninum infection } \\
(\%)\end{array}$ \\
\hline 1 & 64 & 17 & $26.6 \%$ \\
2 & 174 & 51 & $29.3 \%$ \\
3 & 467 & 136 & $29.1 \%$ \\
4 & 368 & 133 & $36.1 \%$ \\
Subtotal & $\mathbf{1 0 7 3}$ & $\mathbf{3 2 4}$ & $\mathbf{3 0 . 2} \%$ \\
\hline
\end{tabular}

The analysis of the results per farm indicated that 91.5\% (43/47) of farms had at least one positive animal. The KDE of the $N$. caninum infection per farms in the state of Amazonas revealed the presence of seropositive animals distributed throughout the all subpopulation of state, indicated rates varied from 2.2 to $69.2 \%$, with the more points of high density found in subpopulation 3 (Figure 2).

A univariate analysis revealed a significant association between $N$. caninum infection in cattle and the following variables: type of herd ( $p=0.009)$; type of livestock farming system $(p=0.012)$; source of water supply $(p=0.000)$; presence of dogs $(p=0.000)$; occurrence of abortion $(p=0.000)$; newborn mortality rate $(p=0.000)$; and birth of weak calves $(p=0.000)$. The following risk factors for cattle in this region were identified by logistic regression: dairy farming $(O R=2.71 ; p=0.021)$, beef farming $(O R=1.61 ; p=0.008)$, herds raised on a combination of dry and flooded lands $(O R=1.54 ; p=0.007)$, source of running water in association with standing water $(O R=2.10 ; p=0.000)$, presence of dogs $(O R=1.80 ; p=0.000)$, occurrence of abortion on the farm $(O R=2.35 ; p=0.000)$ and birth of weak calves (OR=1.88) (see Table 2). 


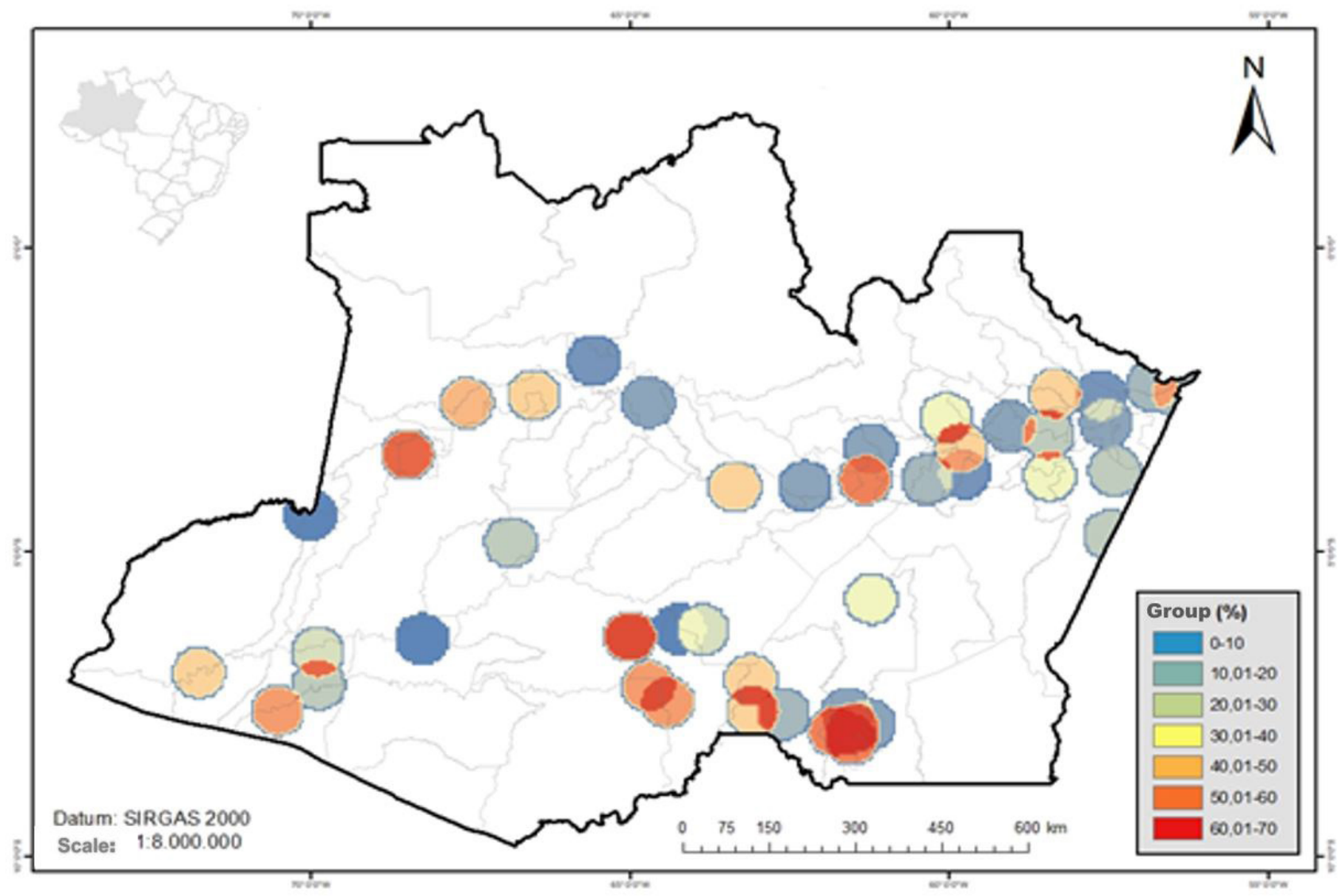

Figure 2. Kernel density estimation of the prevalence of Neospora caninum infection in cattle in the state of Amazonas, Brazil.

\section{Discussion}

To the best of our knowledge, this is the first study on the epidemiology of N. caninum infection in cattle herds in the state of Amazonas, where a prevalence rate of 30.2\% (324/1073) was found. The territory of Amazonas state is covered entirety by the largest tropical forest in the world, the Amazon Rainforest, is a continental size state with sociocultural, economic and political differences, as well as geographical and ecological characteristics that may partly explain the widely varying prevalence rates among the farms (Vasconcelos, 2015). In fact, the reported prevalence rates of $N$. caninum infection in cattle in Brazil vary widely and in the northern region of Brazil, where the state of Amazonas is located, search data is limited.

This is an important and sensitive region of world for the preservation of fauna and flora. However, there has been a growth in deforestation in the region, especially in the last 30 years (IBGE, 2017), one of the main direct causes of livestock and large-scale agriculture, and among these, the expansion of cattle livestock is the most important (Rivero et al., 2009). In this sense, is necessary to encourage the development of a livestock based on productivity supported by scientific data and animal health knowledge.

In Brazil, the presence of $N$. caninum antibodies in cattle has been studied in several areas (Gennari, 2004), but only two of these reports were related to the Amazon region, under management conditions similar to that carried out in this study. Aguiar et al. (2006) in the state of Rondônia and Minervino et al. (2008) in the state of Pará, reported prevalence rates ranging from $10.4 \%$ to $19 \%$. These studies show different seroprevalence values for anti-N. caninum antibodies to those found in our study.

This difference may occur due to the cutoff point used for each study, as well as the breeding conditions for each herd studied. In the Rondônia State, there was not the floodplain system (a kind of wet meadow) and the animals are raised only in cultivated pastures in more intensive conditions; also there are some different climatic conditions in special related to the rainy season period. In the states of Pará and Amazonas, the climatic conditions 
Table 2. Univariate analysis and logistic regression of risk factors associated with Neospora caninum infection in cattle in the state of Amazonas, Brazil.

\begin{tabular}{|c|c|c|c|c|c|}
\hline \multirow{2}{*}{ Variable } & \multirow{2}{*}{ N* } & \multirow{2}{*}{ Positive (\%) } & \multirow{2}{*}{$\begin{array}{c}\text { Univariate } \\
p \text { value }\end{array}$} & \multicolumn{2}{|c|}{ Regression } \\
\hline & & & & OR & $p$ value \\
\hline \multicolumn{6}{|l|}{ Type of herd } \\
\hline Mixed & 214 & $48(22.4 \%)$ & 0.009 & & \\
\hline Beef & 834 & $265(31.8 \%)$ & & $1.61(1.13-2.29)$ & 0.008 \\
\hline Dairy & 25 & $11(44.0 \%)$ & & $2.71(1.15-6.37)$ & 0.021 \\
\hline \multicolumn{6}{|c|}{ Livestock farming system } \\
\hline Dry land & 810 & $227(28.0 \%)$ & 0.012 & & \\
\hline Floodplain & 10 & $2(20.0 \%)$ & & $0.89(0.18-4.35)$ & 0.886 \\
\hline Dry land + Floodplain & 253 & $95(37.6 \%)$ & & $1.54(1.12-2.11)$ & 0.007 \\
\hline \multicolumn{6}{|l|}{ Size of farm (hectare) } \\
\hline$<50$ & 170 & $56(32.9 \%)$ & 0.213 & & \\
\hline 51 to 500 & 626 & $176(28.1 \%)$ & & & \\
\hline$>501$ & 277 & $92(33.2 \%)$ & & & \\
\hline \multicolumn{6}{|l|}{ No. of cattle } \\
\hline $1-10$ animals & 36 & $10(27.8 \%)$ & 0.595 & & \\
\hline $11-50$ animals & 72 & $25(34.7 \%)$ & & & \\
\hline $51-100$ animals & 236 & $77(32.6 \%)$ & & & \\
\hline More than 100 animals & 729 & $221(29.1 \%)$ & & & \\
\hline \multicolumn{6}{|l|}{ Source of water supply } \\
\hline Running water & 306 & $64(20.9 \%)$ & 0.000 & & \\
\hline Still water & 230 & $68(29.6 \%)$ & & $1.58(1.06-2.35)$ & 0.021 \\
\hline Running + Still water & 537 & $192(35.8 \%)$ & & $2.10(1.51-2.91)$ & 0.000 \\
\hline \multicolumn{6}{|l|}{ Presence of dogs } \\
\hline Yes & 737 & $254(34.5 \%)$ & 0.000 & $1.80(1.28-2.52)$ & 0.000 \\
\hline No & 239 & $54(22.6 \%)$ & & & \\
\hline \multicolumn{6}{|l|}{ Occurrence of abortion } \\
\hline Yes & 501 & 199 (39.7\% & 0.000 & $2.35(1.80-3.07)$ & 0.000 \\
\hline No & 572 & 125 (21.9\%) & & & \\
\hline \multicolumn{6}{|l|}{ Birth of weak calves } \\
\hline Yes & 431 & 165 (38.3\%) & 0.000 & $1.88(1.44-2.45)$ & 0.000 \\
\hline No & 642 & $159(4.8 \%)$ & & & \\
\hline
\end{tabular}

*Number of animals tested. P - significance probability. Odds Ratio - is a measure of association between an exposure and an outcome.

are similar, alternating in wetter periods and with greater concentration of rainfall. Condition that can affect the survival of N. caninum oocysts (Minervino et al., 2008).

The analysis of the Kernel density estimation map for $N$. caninum infection in cattle in the state of Amazonas revealed the presence more points density very high in the subpopulation 3 , with at least one animal testing positive for the infection at $91.5 \%$ of the farms involved in this study (Figure 2). The subpopulation 3 represents almost 
$80 \%$ of the bovine population in the state, this concentration of hot areas may be due to the animals staying for a longer time together on the same property, different from subpopulations 1, 2 and 4 that have high turnover of herds and lower population density.

Dairy farms were identified as a risk factor for $N$. caninum infection and were 2.71-fold more likely to have infected cattle. The animal farming system employed by these farms may increase the risk of infection because it is more intensive, thus facilitating the transmission of the parasite. Almería et al. (2009) reported a similar finding that dairy herds are more susceptible to $N$. caninum infection than beef cattle, because this livestock farming system is more intensive, and the animals remain in this system for longer periods.

Raising herds on a combined system of dry and flooded lands, which is exclusively the case of Subpopulation 4, was also identified as a risk factor $(\mathrm{OR}=1.54)$. This mesoregion has two characteristic seasons: the dry season, from July to December, characterized by low water levels of the Amazon River, exposing the naturally fertilized floodplain lands, and the wet season, from January to June, characterized by the rising level of the river, whose waters flood the surrounding lowlands, forcing the riverine population and their livestock, including cattle, to move to higher ground (Filizola et al., 2006). This seasonal flooding causes cattle herds to concentrate on small areas of dry land, where they are in direct contact with dogs and other domestic animals in the surroundings, in livestock sheds and at feed troughs. Conversely, in the dry season, cattle are raised on the floodplains, in collective systems where several species of livestock occupy the same area. Similar findings were reported by Dubey et al. (2007), who demonstrated that husbandry management is a risk factor for environmental contamination by $N$. caninum.

The presence of dogs on the farms was also considered a risk factor in our study. Cattle raised on farms where dogs lived were 1.80-fold more likely to be infected with N. caninum. According to Dubey et al. (2007) and McAllister et al. (1998), the presence of dogs is considered a risk factor, since they are the definitive hosts of N. caninum. Oocysts, the environmentally resistant stage of the parasite, are excreted in dog feces, contaminating the environment and transmitting the parasite to cattle via horizontal transmission through the ingestion of sporulated N. caninum. Ghalmi et al. (2012) found that water sources on a farm are important reservoirs of $N$. caninum oocysts, because they can become contaminated by these infecting forms excreted in the feces of the definitive hosts. The findings of the aforementioned authors corroborate those of our study, which confirmed that animals that drink running water in association with standing water were 2.10-fold more likely to become infected.

A strong correlation was found between abortion and the birth of weak calves on farms where cows tested positive for anti-N. caninum antibodies. This finding is similar to that reported by Boas et al. (2015), who stated that the birth of weak calves, abortions and the presence of $N$. caninum are correlated, and that the occurrence of the disease is closely associated with production losses, as we found in our study. Other studies have demonstrated that the probability of abortion occurring among seropositive cows is two to seven times higher than among seronegative animals (Dubey \& Schares, 2011), and that this risk is 7.4-fold higher among congenitally infected heifers (Thurmond \& Hietala, 1997).

\section{Conclusions}

In this first seroepidemiological study of N. caninum infection in cattle in the state of Amazonas, it was concluded that $N$. caninum is present with high values of seroprevalence, when compared to other cattle producing states in the Amazon region of Brazil. The factors identified in our study can be used as risk indicators, so that control measures can be implemented to prevent infection by $N$. caninum in herds in this region.

\section{Acknowledgements}

The authors gratefully acknowledge the assistance of the staff at the Laboratory of Infectious Diseases of the Federal Rural University of Pernambuco - UFRPE and the staff of the Amazonas Agriculture and Forest Protection Agency (ADAF).

\section{References}

Agência de Defesa Agropecuária e Florestal do Estado do Amazonas - ADAF. Programa Nacional de Vigilância para Febre Aftosa - PNEFA [online]. Manaus: ADAF; 2019 [cited 2019 Fev 23]. Available from: http://www.adaf.am.gov.br/pnefa/ 
Aguiar DM, Cavalcante GT, Rodrigues AAR, Labruna MB, Camargo LMA, Camargo EP, et al. Prevalence of anti-Neospora caninum antibodies in cattle and dogs from Western Amazon, Brazil, in association with some possible risk factors. Vet Parasitol 2006; 142(1-2): 71-77. http://dx.doi.org/10.1016/j.vetpar.2006.06.014. PMid:16857319.

Almería S, López-Gatius F, García-Ispierto I, Nogareda C, Bech-Sàbat G, Serrano B, et al. Effects of crossbreed pregnancies on the abortion risk of Neospora caninum-infected dairy cows. Vet Parasitol 2009; 163(4): 323-329. http://dx.doi.org/10.1016/j. vetpar.2009.04.026. PMid:19464119.

Amaral RLG, Silva LBG, Pinheiro JW Jr, Souza OL No, Leal CAS, Porto WJN, et al. Neospora caninum em bovinos em matadouros de Pernambuco e Alagoas. Pesq Vet Bras 2012; 32(10): 953-966. http://dx.doi.org/10.1590/S0100-736X2012001000002.

Andreotti R, Barros JC, Pereira AR, Oshiro LM, Cunha RC, Figueiredo LF No. Association between seropositivity for Neospora caninum and reproductive performance of beef heifers in the Pantanal of Mato Grosso do Sul, Brazil. Rev Bras Parasitol Vet 2010; 19(2): 119-123. http://dx.doi.org/10.1590/S1984-29612010000200010. PMid:20624350.

Arima E, Barreto P, Brito M. Pecuária na Amazônia: tendências e implicações para a conservação ambiental. Belém: Instituto do Homem e Meio Ambiente da Amazônia; 2005.

Bailey TC, Gatrell AC. Interactive espatial data analysis. Essex: Longman; 1995.

Brasil. Calendário anual de vacinação aftosa. Brasília: Ministério de Agricultura, pecuária e abastecimento; 2019.

Boas RV, Pacheco TA, Melo AL, de Oliveira AC, de Aguiar DM, Pacheco RC. Infection by Neospora caninum in dairy cattle belonging to family farmers in the northern region of Brazil. Rev Bras Parasito/ Vet 2015; 24(2): 204-208. http://dx.doi.org/10.1590/S198429612015035. PMid:26154960.

Cerqueira-Cézar CK, Calero-Bernal R, Dubey JP, Gennari SM. All about neosporosis in Brazil. Rev Bras Parasitol Vet 2017; 26(3): 253-279. http://dx.doi.org/10.1590/s1984-29612017045. PMid:28876360.

Donahoe SL, Lindsay SA, Krockenberger M, Phalen D, Slapeta J. A review of neosporosis and pathologic findings of Neospora caninum infection in wildlife. Int J Parasitol Parasites Wildl 2015; 4(2): 216-238. http://dx.doi.org/10.1016/j.ijppaw.2015.04.002. PMid:25973393.

Dubey JP, Schares G, Ortega-Mora LM. Epidemiology and control of neosporosis and Neospora caninum. Clin Microbiol Rev 2007; 20(2): 323-367. http://dx.doi.org/10.1128/CMR.00031-06. PMid:17428888.

Dubey JP, Schares G. Neosporosis in animals: the last five years. Vet Parasitol 2011; 180(1-2): 90-108. http://dx.doi.org/10.1016/j. vetpar.2011.05.031. PMid:21704458.

Filizola N, Silva AV, Santos AMC, Oliveira MA. Cheias e Secas na Amazônia: breve abordagem de um contraste na maior bacia hidrográfica do globo. T\&C Amaz 2006; 9: 42-49.

Gennari SM. Neospora caninum no Brasil: situação atual da pesquisa. Rev Bras Parasitol Vet 2004; 13(Supl 1): $23-28$.

Ghalmi F, China B, Ghalmi A, Hammitouche D, Losson B. Study of the risk factors associated with Neospora caninum seroprevalence in Algerian cattle populations. Res Vet Sci 2012; 93(2): 655-661. http://dx.doi.org/10.1016/j.rvsc.2011.12.015. PMid:22244708.

Gondim LF, Sartor IF, Hasegawa M, Yamane I. Seroprevalence of Neospora caninum in dairy cattle in Bahia, Brazil. Vet Parasitol 1999; 86(1): 71-75. http://dx.doi.org/10.1016/S0304-4017(99)00129-6. PMid:10489205.

Hasegawa MY, Sartor IF, Canavessi AMO, Pinckney RD. Ocorrência de anticorpos anti-Neospora caninum em bovinos de corte e em cães rurais da região de Avaré, estado de São Paulo, Brasil. Semina: Ciênc Agrár 2004; 25(1): 45-50. http://dx.doi.org/10.5 433/16790359.2004v25n1p45.

Instituto Brasileiro de Geografia e Estatístca - IBGE. Censo agropecuário [online]. Rio de Janeiro: IBGE; 2017 [cited 2019 Fev 23]. Available from: https://www.ibge.gov.br/ estatisticas/economicas/agricultura-e-pecuaria/21814-2017-censo-agropecuario.html?= \&t=resultados

Kim PCP, Melo RPB, Almeida JC, Silva JG, Ribeiro-Andrade M, Porto WJN, et al. Serological response to Neospora caninum infection in goats and agreement between three diagnostic techniques to detect caprine neosporosis. Pesq Vet Bras 2019; 39(1): 25-31. http://dx.doi.org/10.1590/1678-5150-pvb-5989.

Martins NEX, Freschi CR, Baptista F, Machado RZ, Freitas FLC, Almeida KS. Ocorrência de anticorpos anti-Neospora caninum em vacas lactantes do município de Araguaína, estado do Tocantins, Brasil. Rev Patol Trop 2011; 40(3): 231-238. http://dx.doi. org/10.5216/rpt.v40i3.15973.

McAllister MM, DubeyJP, Lindsay DS, Jolley WR, Wills RA, McGuire AM. Rapid communication: dogs are definitive hosts of Neospora caninum. Int J Parasitol 1998; 28(9): 1473-1478. http://dx.doi.org/10.1016/S0020-7519(98)00138-6. PMid:9770635.

McAllister MM. Diagnosis and control of bovine neosporosis. Vet Clin North Am Food Anim Pract 2016; 32(2): 443-463. http:// dx.doi.org/10.1016/j.cvfa.2016.01.012. PMid:27161392. 
Minervino AHH, Ragozo AMA, Monteiro RM, Ortolani EL, Gennari SM. Prevalence of Neospora caninum antibodies in cattle from Santarém, Pará, Brazil. Res Vet Sci 2008; 84(2): 254-256. http://dx.doi.org/10.1016/j.rvsc.2007.05.003. PMid:17619028.

Pinheiro RR, Gouveia AMG, Alves FSF, Haddad JPA. Aspectos epidemiológicos da caprinocultura cearense. Arq Bras Med Vet Zootec 2000; 52(5): 534-543. http://dx.doi.org/10.1590/S0102-09352000000500021.

Regidor-Cerrillo J, Gómez-Bautista M, Del Pozo I, Jiménez-Ruiz E, Aduriz G, Ortega-Mora LM. Influence of Neospora caninum intra-specific variability in the outcome of infection in a pregnant BALB/c mouse model. Vet Res 2010; 41(4): 52. http://dx.doi. org/10.1051/vetres/2010024. PMid:20416260.

Reichel MP, Alejandra Ayanegui-Alcérreca M, Gondim LF, Ellis JT. What is the global economic impact of Neospora caninum in cattle - The billion dollar question. Int J Parasito/ 2013; 43(2): 133-142. http://dx.doi.org/10.1016/j.ijpara.2012.10.022. PMid:23246675.

Rivero S, Almeida O, Ávila S, Oliveira W. Pecuária e desmatamento: uma análise das principais causas diretas do desmatamento na Amazônia. Nova Econ 2009; 19(1): 41-66. http://dx.doi.org/10.1590/S0103-63512009000100003.

Silva JB, Nicolino RR, Fagundes GM, Dos Anjos Bomjardim H, Dos Santos Belo Reis A, da Silva Lima DH, et al. Serological survey of Neospora caninum and Toxoplasma gondii in cattle (Bos indicus) and water buffaloes (Bubalus bubalis) in ten provinces of Brazil. Comp Immunol Microbiol Infect Dis 2017; 52: 30-35. http://dx.doi.org/10.1016/j.cimid.2017.05.005. PMid:28673459.

Thrusfield MV. Epidemiologia veterinária. 2. ed. São Paulo: Roca; 2004.

Thurmond MC, Hietala S. Effect of Neospora caninum infection on milk production in first-lactation dairy cows. J Am Vet Med Assoc 1997; 210(5): 672-674. PMid:9054999.

Valentim JF, Andrade CMS. Tendências e Perspectivas da Pecuária Bovina na Amazônia Brasileira. Amazônia. Ci \& Desenv 2009; 4(8): 9-32.

Vasconcelos PGA. Determinantes do desmatamento na Amazônia Brasileira [dissertação]. Brasília: Universidade de Brasília; 2015. http://dx.doi.org/10.26512/2015.03.D.18516.

Vianna LC, Sartor IF, Pituco EM, Okuda HL, Camargo CN, Kronka SN. Incidence and transplacental transmission of Neospora caninum in primiparous females from Bos indicus slaughtered in Presidente Prudente, São Paulo, Brazil. Semina: Ciênc Agrár 2008; 29(2): 387-392. http://dx.doi.org/10.5433/1679-0359.2008v29n2p387. 